Article

\title{
Did the Research Faculty at a Small Canadian Business School Publish in "Predatory" Venues? This Depends on the Publishing Blacklist
}

\author{
Panagiotis Tsigaris ${ }^{1, *}$ and Jaime A. Teixeira da Silva ${ }^{2, *}$ \\ 1 Department of Economics, Thompson Rivers University, 805 TRU Way, Kamloops, BC V2C 0C8, Canada \\ 2 Independent, P.O. Box 7, Miki-Cho Post Office, Ikenobe 3011-2, Kagawa-ken 761-0799, Japan \\ * Correspondence: ptsigaris@tru.ca (P.T.); jaimetex@yahoo.com (J.A.T.d.S.)
}

Received: 4 February 2019; Accepted: 14 May 2019; Published: 20 May 2019

\begin{abstract}
The first ever quantitative paper to claim that papers published in so-called "predatory" open access (OA) journals and publishers were financially remunerated emerged from Canada. That study, published in the Journal of Scholarly Publishing (University of Toronto Press) in 2017 by Derek Pyne at Thompson Rivers University, garnered wide public and media attention, even by renowned news outlets such as The New York Times and The Economist. Pyne claimed to have found that most of the human subjects of his study had published in "predatory" OA journals, or in OA journals published by "predatory" OA publishers, as classified by Jeffrey Beall. In this paper, we compare the so-called "predatory" publications referred to in Pyne's study with Walt Crawford's gray open access (grayOA) list, as well as with Cabell's blacklist, which was introduced in 2017. Using Cabell's blacklist and Crawford's grayOA list, we found that approximately $2 \%$ of the total publications (451) of the research faculty at the small business school were published in potentially questionable journals, contrary to the Pyne study, which found significantly more publications (15.3\%). In addition, this research casts doubt to the claim made in Pyne's study that research faculty members who have predatory publications have 4.3 "predatory" publications on average.
\end{abstract}

Keywords: open access; Beall's lists; Cabell's blacklist; Gray OA; false positives

\section{Introduction}

Academic publishing is full of challenges and is in a dynamic state of change. One of the most challenging of these is the issue of "predatory" publishing, a concept that came to the fore of the discussion on academic publishing when a US librarian, Jeffrey Beall, started a blog that denounced what he perceived to be unscholarly activities by select open access (OA) journals and publishers. Beall referred to such entities as "predatory" OA journals and publishers, hereafter POAJs and POAPs, respectively. As Beall recorded more and more cases, his blog rapidly gained popularity. Beall created two blacklists that would prove to be the subject of great controversy, and both praise and criticism, namely one for POAJs and a separate one for POAPs. Using a set of established criteria, which were broad and qualitative in nature, Beall began to list hundreds of new POAJs and POAPs annually, and his list of POAPs exceeded 1000 entries at the beginning of 2017. The publication of those blacklists may have been one partial reason for the shuttering of Beall's blog, as was suggested by Beall himself [1]. ${ }^{1}$ Before then, Beall had called on the ban of such POAJs and POAPs [2], but was cautious by referring to them widely and loosely as "potentially, possible or probable predatory". However, entities sensu lato

$1 \quad$ Without warning, Beall shut his blog down on 15 January 2017. 
profiled on that blog or associated with either blacklist may have suffered reputational damage. Rather than observing the merit or demerit of each individual paper, select academics started a new trend in which they were judged based on the venue where they had published by using Beall's blacklists of POAJs and POAPs as their guiding measure. Reputational damage caused by the existence and misuse of blacklists is one of their caveats [3].

Beall developed a first, second and third edition of criteria to determine "potential, possible, or probable" POAJs and POAPs. ${ }^{2}$ Each edition was presumably created to have an increased power to detect a true predatory journal. This power is similar to the sensitivity rate of screening tests for diseases in the field of medicine [4]. In the medical field, the sensitivity rate shows the power of screening tests to identify a particular disease from a sample of patients who have the illness (i.e., a true positive). In this framework, the power of the criteria is to detect predatory behavior from a sample of journals that are predatory. However, even the third edition was not 100\% powerful, and could not detect all POAJs and POAPs. In addition, screening tests, and hence criteria, should have the power to detect true non-predatory entities and exclude these from a blacklist. This is the specificity rate in medicine [4]. It is the strength of the medical tests to not detect a particular disease for a sample of patients who do not have the disease (i.e., a true negative). In this framework, it is the power of the criteria to detect non-predatory journals and publishers from a sample of journals that are in fact non-predatory. A reduction in the latter power (the specificity rate) increases the rate of including non-predatory journals and publishers in the list erroneously based on the criteria (i.e., a false positive). A false positive, i.e., accepting that a journal or publisher is "predatory" (i.e., a POAJ or a POAP) when it is not, is very possible given the general and possibly erroneous nature of Beall's criteria. Olivarez et al. [5] stated: "An evaluator might label a scholarly journal as "predatory" when it is not, or may disregard the article as being without merit solely because it is published in a journal found on Beall's List." Their study found that out of 81 well-regarded academic journals in the field of library and information science, 45 (i.e., over $50 \%$ ) were "predatory" using Beall's criteria by an independent panel of three experts, but were academically valid according to these subject experts. ${ }^{3}$ This shows a very low specificity rate and hence a very high false positive rate when using Beall's criteria to assess deceptive practices of publishers and journals. That study confirmed that Beall's lists were highly flawed and thus misleading, fortifying earlier claims [6-8]. A very recent study [9] concluded that the "common views about predatory journals, (e.g., no peer review) may not always be true, and that a grey zone between legitimate and presumed predatory journals exists".

In a 2016 blog $^{4}$ entry, Walt Crawford found that Beall's blacklists were unreliable and flawed [10], a notion supported by Teixeira da Silva [6,7]. Crawford argued that those blacklists were based on circumstantial evidence and on the concept of "just because", and constructed on the basis of "trust me". Crawford critically assessed Beall's blog from 2012 to January 2016 and across all posts could only find some discussion in the blog for only 230 (53 journals and 177 publishers) of the 1834 journals and publishers in Beall's 2016 POAJ and POAP blacklists. Hence, no clear criteria or independently verifiable reasons for the inclusion of $87.5 \%$ of the journals and publishers on Beall's

2 The 1st edition was published on 4 August 2012: https://scholarlyoa.files.wordpress.com/2012/08/criteria-2012.pdf. The 2nd edition was published on 1 December 2012: https://scholarlyoa.files.wordpress.com/2012/11/criteria-2012-2.pdf. The 3rd edition was published on 1 January 2015: http://beallslist.weebly.com/uploads/3/0/9/5/30958339/criteria-2015.pdf. We do not know which of the above criteria, if any, Pyne used to classify the journals in his Journal of Scholarly Publishing JSP paper as "predatory". We suspect that he blindly, i.e., without questioning the validity of the entries, followed Beall's lists for classification.

3 MDPI has expressed serious concerns with Beall's list: “We wish to conclude by expressing that Mr. Beall's blacklist in its current form is unnecessary and unreliable." "Mr. Beall operates as an individual person and does not provide sufficient evidence for his claims, does not attempt to verify his statements for accuracy, nor operate a methodological approach to his appraisals. Mr. Beall also denies the right to defense to those that he attacks. Mr. Beall's judgments are therefore to be considered as unreliable, unmethodical and his personal opinions." See: https://www.mdpi.com/about/announcements/534. See https://walt.lishost.org/2016/01/trust-me-the-other-problem-with-87-of-bealls-lists/. 
blacklists could be accounted for. This massive discrepancy suggests how misleading and erroneous Beall's blacklists were.

Crawford created a list of these $230 \mathrm{OA}$ journals and publishers and, depending on the discussions in Beall's blog from 2012-2016, classified them as being either "no", "weak", "maybe" or "strong" cases of deceptive practices. ${ }^{5}$ Crawford concluded that five were "no" cases (2.2\%), 69 were "weak" cases $(20 \%), 43$ were "maybe" cases $(18.7 \%)$ and 113 were "strong" cases $(49.1 \%)$. These findings by Crawford are important as they show how unreliable Beall's blacklists were and that any research based on these lists, such as a 2017 paper by Derek Pyne at Thompson Rivers University in the Journal of Scholarly Publishing (JSP; University of Toronto Press) [11], would likely be extremely faulty. This risk was clearly stated by Crawford on his blog. ${ }^{6}$

However, the influence by Beall and his blacklists was profound. Beall retired in early 2018. ${ }^{7}$ During his several years dominating this topic, Beall was widely cited, either in the form of his blog, or his own publications. Now, after the closure of his blog [12], an important post-publication peer review (PPPR) of the literature that Beall published, as well as the literature that cited him, his blog, or his blacklists, is needed. This is because, in essence, papers that use Beall's blacklists of POAJs and POAPs may have been making serious methodological errors, by transferring Beall's false positives into their research which would compound the false positives they might face with their own research. Since Beall's blacklists carry false positives, any methodology that used, or relied on them, could be automatically flawed by association [3]. Thus, studies that used Beall's blacklists for any quantitative analyses may be intrinsically flawed and should be subject to careful scrutiny and correction, if necessary.

Within the PPPR analysis of Beall-influenced literature, we discuss a paper that was covered by many media outlets. ${ }^{8}$ A study (hereafter, "the Study") by Pyne [11] made the first ever claim that academics were being remunerated, and thereby rewarded, based on "predatory publications", i.e., papers published in Beall-listed POAJs and POAPs. The Study claimed that researchers at a small business school in Canada were being financially rewarded for having published "predatory publications", a claim that was refuted by Tsigaris in January 2019 [13].

The Study drew several conclusions ${ }^{9}$ about the link between the research faculty members at the small business school and "predatory publications". However, in this paper, we focus on the following two:

a. "The majority of faculty with research responsibilities at a small Canadian business school have publications in predatory journals" (abstract, p. 137).

b. "Even honest researchers make mistakes and can be fooled into publishing in predatory journals. However, when researchers demonstrate a pattern of publishing in such journals, suspicions increase." "It can be seen that 75 per cent of traditional faculty who have predatory journal publications have more than one such publication. Moreover, traditional faculty who have predatory publications have, on average, 4.3 predatory publications." (p. 150).

5 Crawford did not use the term "predatory" once in his critique of Beall's blacklists and exclusively used the categories "no", "weak", "maybe" and "strong" to identify if Beall had provided clear criteria for those entries (journal or publishers).

6 "In seven cases out of eight (on the 2016 lists), Beall provides no case whatsoever in his blog: the journal or publisher is in the lists Just Because. (Or, in some but not most cases, Beall provided a case on his earlier blog but failed to copy those posts.) Seven cases out of eight: $87.5 \% .1604$ journals and publishers of the 1834 (excluding duplicates) on the 2016 versions have no more than an unstated "trust me" as the reason for avoiding them. I believe that's inexcusable, and makes the strongest possible case that nobody should treat Beall's lists as being significant. (It also, of course, means that research based on the assumption that the lists are meaningful is fatally flawed.)" Italics added by the authors for emphasis.

7 https://twitter.com/jeffrey_beall?lang=en ("I am retired").

8 http://ottawacitizen.com/opinion/columnists/pyne-are-universities-complicit-in-predatory-publishing; $\quad$ http: //retractionwatch.com/2017/05/09/faculty-publish-predatory-journals-school-become-complicit/; https:/www.nytimes. com/2017/10/30/science/predatory-journals-academics.html.

9 Note these are direct quotes from the JSP paper, i.e., Pyne's own words. Italics and [ ... ] were added by the authors for emphasis and brevity, respectively. 
The Study concluded that many research faculty members at a small Canadian business school published in "predatory" journals. ${ }^{10}$ In fact, the Study used the expression "predatory" over 100 times. The Study never used the term "potentially, possible or probable predatory", as Beall had suggested. ${ }^{11}$ Was this done to create an illusionary truth effect [14]? Beall had to be cautious about the way he created and advertised his blacklists to reduce legal liability, so he used the terms "potential, possible, or probable predatory publishers and journals", which can range from not predatory at all to highly predatory, but always implying doubt about any entry on those POAJ and POAP blacklists. Despite this, Beall still encouraged faculty not to publish in these journals. ${ }^{12}$ Furthermore, there is a huge gray area that separates poorly managed, start-up and academically questionable journals or publishers, and journals whose only objective was to exploit authors, categories that Beall failed to clearly separate.

In summary, this paper focuses on how Pyne's results would change if Walt Crawford's gray open access list (grayOA), which was in existence at the time of the Study, as well as Cabell International's (hereafter Cabell's) blacklist, had been used. The latter was not available to Pyne at that time but is now, since the small business school currently subscribes to Cabell's blacklist. We found significantly different results with the use of Crawford's grayOA as well as Cabell's blacklist, and found that only a small number of publications were potentially questionable. ${ }^{13}$ This research can also be seen independently of the Study under investigation, i.e., the Study was not necessary to conduct this research. The authors have collected the information that is in the public domain for the 27 research faculty members of the small business school and compare the three lists.

\section{Methodology}

In order to conduct our research, we needed the data of the small business school's research faculty. Unfortunately, Pyne refused to provide the data to the authors of this article when requested in the summer and winter of 2017 and a formal complaint was filed with Pyne's university in late 2017 requesting this data. To date, Pyne has still not made his data available for reanalysis. Hence, we collected the data ourselves for the 27 research faculty members based on searches on Google, Google Scholar, Researchgate, and faculty members' websites. ${ }^{14}$ We did not find the exact same number of publications as were reported by Pyne, as we show in the results section, reinforcing the need to have access to Pyne's original data set. We also used the Australian Business Dean's Council (ABDC) whitelist to rank the journals. The ABDC whitelist, which ranks business and economics journals, has been used by the research faculty from 2011 onwards to identify suitable research outlets and was also used by the Study to classify journals into $A^{*}, A, B$, and $C$ categories, as defined by ABDC. The Study also classified faculty members' publications as either being on the ABDC whitelist or Beall's blacklists, or both. The 2013 ABDC list, which includes many Beall-blacklisted POAJs and POAPs, was used in the Study. However, after Beall made headlines with his lists around 2013,

10 There is only one place in the JSP manuscript where Pyne mentioned the possibility of Beall's list being inaccurate: “Any list such as Beall's will have both type I errors (i.e., wrongly included journals)" (p. 143), but softened this type of error by adding the possibility of "type II errors (journals being wrongly excluded)" (p. 143).

11 For example, the string of words "predatory publication" in Table 4 appears seven times. A word search of "predatory publication" occurs in 46 places while a search for the word "Beall" appears 42 times. The words "potential, possible or probable predatory" has not been used once, individually or as a string of words. Why did Pyne not use the terms "Beall's lists" or "Beall's blacklists" or the "lists", but instead opt to use the definitive term "predatory"?

12 See, as an example: "Recommendation: Do not do business with the above publishers, including submitting article manuscripts, serving on editorial boards, buying advertising, etc. There are numerous traditional, legitimate journals that will publish your quality work for free, including many legitimate, open-access publishers." http://www.ep.liu.se/authorinf/ pdf/List_of_Predatory_Open-Access_Publishers_2012.pdf (Beall, J. 2012. Beall's List of Predatory, Open-Access Publishers).

13 Throughout this paper, we have add inverted commas for the term "predatory" because this term is used widely by so many academics and has come to represent a vast range of journals and publishers with varying academic quality. This paper does not propose to offer a review on the topic of "predatory publishing", as several papers on this literature are polemic and need to be formally challenged and reevaluated, because some of the claims that they have made may in fact be potentially inaccurate. For all effective purposes, we focus exclusively on the Pyne (2017) JSP paper [11].

14 The current policy at the small business school currently exempts research that uses publicly available data from ethics approval, as occurred for the Pyne (2017) JSP paper [11]. 
ABDC reevaluated their list and a new 2016 ABDC list was created. ${ }^{15}$ Potentially influenced by Beall, they removed some Beall-listed journals and publishers and maintained others on the ABDC list. This ndicates that ABDC believed that these journals were not "predatory", i.e., that these journals were academically valid and scholarly, unlike what Beall had claimed. ${ }^{16}$

\section{Results}

Table 1 provides a summary of our findings and a comparison to the Study, which can be estimated from table 5 of the Study. Our summary for this table presents publications results that are not pro-rated by the number of authors, just like the Study's table 5, from which we made an inference. We are short by one article in total. We found the same number of $A^{*}$ journal publications, we are short of two $A$ publications, we have one more $B$ journal and one less $C$ journal. However, the largest divergence occurred with the ranked and Beall category. We found a total of 31 journal publications in the ranked and Beall category while the Study found 41 in this category across the 27 research faculty members, i.e., 10 less publications than the Study found. ${ }^{17}$ We did not include Inderscience and World Scientific Publishers as they did not appear in Beall's POAP blacklist and we do not know if the Study classified these two publishers as "predatory", i.e., as POAPs.

Table 1. Journal rankings by Pyne versus our assessment.

\begin{tabular}{ccccccccc}
\hline & A $^{*}$ & A & B & C & Ranked + Beall's & Beall's & Unclassified & Total \\
\hline Our assessment & 21 & 51 & 109 & 95 & 31 & 31 & 113 & 451 \\
Pyne's totals & 21 & 53 & 108 & 96 & 41 & 28 & 105 & 452 \\
Difference & 0 & -2 & 1 & -1 & -10 & +3 & +8 & -1 \\
\hline
\end{tabular}

Table 1 shows a distribution that is typical over a representative career of a faculty member at the "small" teaching-focused university. There is a lower frequency of $\mathrm{A}^{*}$ journal publications, then $\mathrm{A}$ journals and it peaks in the $B$ range, drops in the $C$ range, relative to $B$, and is low in the ABDC ranked plus Beall's and Beall's and unranked then rises again for the unclassified journals. The Study stressed (in the published JSP paper and in the media), that most of the faculty members published "predatory publications" in POAJs and POAPs. However, Table 1 shows a completely different picture, even when the Study's results are used. We then used Crawford's grayOA classification and Cabell's blacklist to reclassify the Study's classification. We wanted to know whether the use of Crawford's grayOA would change the results and the Study's conclusions significantly as it relates to Beall's ranked and unranked in the ABDC listing. We also wanted to know what our data would show independently of the Study. Our findings are presented below.

\subsection{Findings on Beall's + Ranked in the ABDC Listing Journal Publications (Table 2) ${ }^{18}$}

Table 2 shows publication outlets of research faculty members at the small Canadian business school in journals listed on Beall's 2016 blacklist as well as the 2013 ABDC whitelist. $^{19}$

The first column of Table 2 shows the journals in Beall's lists that were also in the ABDC 2013 listing which were publication outlets of the small business school's research faculty. The second column shows the publisher. The third column shows the number of articles published in these journals. This is followed by Crawford's assessment of Beall's list of journals and publishers that Pyne assumed

15 http://www.abdc.edu.au/pages/2016-review.html; it is unclear if Pyne used this or the 2013 list.

16 In all fairness, this also indicates that the ABDC whitelist was, to some extent, flawed, or imperfectly curated.

17 We did not include Inderscience and World Scientific Publishing. We do not know if Pyne confused Inderscience, which is not on Beall's POAP list, with Interscience, which is on Beall's POAP list as well as World Scientific Publishing, which is not on Beall's POAP list, with World Science Publishing, which is on Beall's POAP list.

18 Supplementary Table S1 shows the name and URL of these journals/publishers.

19 We have not listed papers published by Inderscience and World Scientific Publishing. 
was "predatory". The ranking in the 2013 ABDC list and the 2016 ABDC list is shown next. The next column shows whether these journals are listed in the 2017 Econ Lit, which is an important directory that business and economy faculty around the world use to find suitable research outlets. ${ }^{20}$ The next column shows if the journal is fully OA or not. ${ }^{21}$ We then show Cabell's assessment of these journals in terms of being listed in the past, as to whether they are in its whitelist or its in 2017-created blacklist. ${ }^{22}$

Table 2 shows 16 journals in the Beall's + ABDC ranked category. Nine journals are fully OA and seven are not $\mathrm{OA}$. The non-OA are the journals published by the International Academy of Business and Economics (IABE), the Indian Journal of Economics and Business by Serials Publications and the Journal of Applied Business and Economics by North American Business Press. This shows that Beall erred in thinking that IABE journals are OA. ${ }^{23}$ There were 29 articles published in these journals, mostly one article in each journal with a few having more than one article published, but by different faculty members. Using Crawford's taxonomy, 11 out of 16 journals were based on "trust me" (i.e., Beall did not provide an explanation of how the journal satisfied the criteria for inclusion on his 2016 list, accounting for $69 \%$ of the journals). Crawford stated: "Research based on the assumption that the lists are meaningful is fatally flawed." In other words, the Study labelled the research faculty members at the small Canadian business school based on trust that Beall's lists were factually correct in their assessment of the journals' and publishers' academic and scholarly status. Cross checking with Crawford's spreadsheet ${ }^{24}$, only two journals from the 16 received the "strong" label for being "predatory", one was listed as "maybe" and two were considered "weak".

ABDC removed seven journals from their 2016 whitelist. ${ }^{25}$ They removed the two "strong" cases and two "weak" cases but maintained the "maybe" case of Crawford's cross check. Three articles appear in the Journal of International Management Studies which were published in 2009, 2010 and 2012 by three different faculty members when Beall's blog was at its infancy with very few obscure journals and publishers in his lists. The paper in the Journal of Global Business Management was published in 2013 while the paper in Theoretical Economics Letters was published in 2014, which was still in the ABDC whitelist used by the profiled faculty members to find suitable publishing outlets, i.e., Theoretical Economics Letters was a valid publishing venue. Hence, we found a total of five articles published in POAJs and POAPs, provided the Crawford-based "maybe" and "strong" cases are selected. Even so, the peer reviewed nature, as well as academic validity and scholarly nature of individual papers within those journals remains unknown and untested. Only $1.2 \%$ of the total publications of the 27 tripartite faculty could be considered as "predatory", and not the staggering $15.3 \%$ (from a total of his 452 publications count) that Pyne found in his Study.

In terms of Cabell's listing, out of the 16 journals in Table 2, only one was not listed in Cabell's whitelist in the past. Cabell included 15 of the 16 journals (94\%) in their whitelist in the past but removed six of these journals in April 2014 and another six after April 2015. Three journals out of the 16 in Table 2 are in Cabell's blacklist and four are not while the remaining nine are under review to date. ${ }^{26}$

20 https://www.aeaweb.org/econlit/journal_list.php.

21 Beall's list was strictly limited to OA journals, although there were occasional exceptions, such as Nova Science Publications (NY, USA). Did Pyne use any hybrid or non-OA journals or publishers for his classification? This issue is not clear in his paper. For example, Pyne lists the International Academy of Business and Economics (IABE). However, IABE is not an OA publisher, at least not now. So, the issue of congruency between Beall's lists and Pyne's lists, and if both focused exclusively on OA journals and publishers, remains unclear.

22 Cabell's whitelist and blacklist can be accessed at: http://www.cabells.com/ (membership required).

23 For example, see FAQ in one of the journals: http://ejbr-journal.org/domains/EJBR-JOURNAL/Default.aspx.

24 Can be accessed at Crawford's website or available upon request.

25 The list was last downloaded on 16 May 2018: http://www.abdc.edu.au/pages/2016-review.html.

26 The three blacklisted journals by Cabell's are The Asian Social Science and the International Journal of Business and Management by the Canadian Center of Science and Technology which Crawford labels as "weak" and the Indian Journal of Economics and Business by Serials Publications which Crawford labels as "trust me". Cabell's blacklist was last verified on 16 May 2018. 
Table 2. Publications of research faculty members in Beall's 2016 list and ranked in the 2013 ABDC whitelist.

\begin{tabular}{|c|c|c|c|c|c|c|c|c|c|c|c|c|}
\hline \multirow[b]{2}{*}{ Journal } & \multirow[b]{2}{*}{ Publisher } & \multirow[b]{2}{*}{$\begin{array}{l}\text { \# of } \\
\text { Articles }\end{array}$} & \multirow[b]{2}{*}{ Crawford } & \multirow[b]{2}{*}{$\begin{array}{l}\text { ABDC } \\
2013\end{array}$} & \multirow[b]{2}{*}{$\begin{array}{l}\text { ABDC } \\
2016\end{array}$} & \multirow[b]{2}{*}{ EconLit } & \multirow[b]{2}{*}{$\begin{array}{l}\text { Open } \\
\text { Access }\end{array}$} & \multicolumn{5}{|c|}{ Cabell's Classification } \\
\hline & & & & & & & & $\begin{array}{l}\text { Starting Date of } \\
\text { Inclusion in } \\
\text { Whitelist } \\
\text { (month, year) }\end{array}$ & $\begin{array}{c}\text { Date } \\
\text { Removed } \\
\text { (month, year) }\end{array}$ & Again in & $\begin{array}{c}\text { Currently } \\
\text { Whitelisted }\end{array}$ & Blacklisted \\
\hline $\begin{array}{l}\text { Academy of Marketing } \\
\text { Studies Journal }\end{array}$ & Allied Academies & 1 & Trust me & $\mathrm{C}$ & Y & & Y & January 1997 & August 2015 & $\begin{array}{l}\text { March-October } \\
2016\end{array}$ & No & No \\
\hline Asian Social Science & $\begin{array}{l}\text { Canadian Center of } \\
\text { Science and } \\
\text { Education }\end{array}$ & 1 & Weak & C & & & $\mathrm{Y}$ & June 2010 & April 2015 & & No & Yes \\
\hline $\begin{array}{l}\text { Indian Journal of Economics } \\
\text { and Business }\end{array}$ & Serials Publications & 2 & Trust me & C & Y & & No & January 2004 & June 2015 & & No & Yes \\
\hline $\begin{array}{l}\text { International Journal of } \\
\text { Business and Management }\end{array}$ & $\begin{array}{c}\text { Canadian Center of } \\
\text { Science and } \\
\text { Education } \\
\end{array}$ & 3 & Weak & $\mathrm{C}$ & & & Y & June 2010 & April 2015 & & No & Yes \\
\hline $\begin{array}{l}\text { The International Journal } \\
\text { of Management }\end{array}$ & IJM & 1 & Trust me & $\mathrm{C}$ & $\mathrm{Y}$ & & Y & January 1998 & April 2013 & & No & Under review \\
\hline $\begin{array}{l}\text { Journal of Academy of } \\
\text { Business and Economics }\end{array}$ & IABE & 1 & Trust me & C & $\mathrm{Y}$ & & Hybrid & January 2004 & April 2014 & & No & Under review \\
\hline $\begin{array}{l}\text { Journal of Applied Business } \\
\text { and Economics }\end{array}$ & $\begin{array}{l}\text { North American } \\
\text { Business Press }\end{array}$ & 1 & Trust me & C & $\mathrm{Y}$ & & No & January 2006 & & & Yes & No \\
\hline $\begin{array}{l}\text { Journal of Business and } \\
\text { Economics Research }\end{array}$ & Clute Institute & 3 & Trust me & C & Y & & Y & January 2010 & April 2014 & & No & No \\
\hline $\begin{array}{l}\text { The Journal of Global } \\
\text { Business Management }\end{array}$ & JGBM & 1 & Strong & C & & & Y & January 2010 & August 2016 & & No & Under review \\
\hline $\begin{array}{l}\text { Journal of International } \\
\text { Business and Economics }\end{array}$ & IABE & 4 & Trust me & $\mathrm{C}$ & & $\mathrm{Y}$ & Hybrid & January 2004 & April 2014 & & No & Under review \\
\hline $\begin{array}{l}\text { Journal of International } \\
\text { Finance and Economics }\end{array}$ & IABE & 3 & Trust me & C & $\mathrm{Y}$ & Y & Hybrid & January 2006 & April 2014 & & No & Under review \\
\hline $\begin{array}{l}\text { Journal of International } \\
\text { Financial Studies }\end{array}$ & IABE & 2 & Trust me & C & & $\mathrm{Y}$ & Hybrid & & & & No & Under review \\
\hline $\begin{array}{c}\text { The Journal of International } \\
\text { Management Studies }\end{array}$ & JIMS & 3 & Strong & $\mathrm{C}$ & & & Y & January 2010 & April 2014 & & No & Under review \\
\hline Review of Business Research & IABE & 1 & Trust me & C & & $\mathrm{Y}$ & Hybrid & January 2004 & April 2014 & & No & Under review \\
\hline Theoretical Economics Letters & $\begin{array}{c}\text { SCIRP (Scientific } \\
\text { Research Publishing) }\end{array}$ & 1 & Maybe & B & $\mathrm{Y}$ & $\mathrm{Y}$ & $\mathrm{Y}$ & August 2012 & April 2014 & & No & Under review \\
\hline
\end{tabular}


In summary, the faculty members at a small Canadian business school who were profiled by the Study used the 2013 ABDC list and continue to use the 2016 ABDC list. They also used Cabell's listing to find publication outlets and were not aware of Beall's blacklists. Hence, we disagree with Pyne's statements suggesting that the majority of the faculty members at a small Canadian business school published in predatory journals (quote a) and that they knowingly published in Beall's lists s (quote b).

\subsection{Beall's + Not Ranked in the ABDC Listed Journals (Table 3$)^{27}$}

In terms of Beall's + "not ranked in ABDC list" (the Study's classification), Table 3 classifies the journals in which the research faculty published. There are a total of 17 journals in Table 3 . In this case, all journals, except one, are fully OA. Here too, only two journals are "strong" cases, one is a "maybe" and two were classified as "weak", as defined by Crawford. ${ }^{28}$ The remaining journals were based on "trust me" (70\%; 12/17). A total of three journals show some evidence of being "predatory" if one considers the "maybe" and "strong" cases. Strong cases are the International Journal of Applied Engineering Research by Research India Publications published in 2015, and OIDA International Journal of Sustainable Development by Zzind published in 2014. The "maybe" case is the Open Journal of Social Sciences by SCIRP (Scientific Research Publishing), also published in 2015. Only three could be "predatory" from Table 3 and this constitutes $0.7 \%$ of the total of 451 publications of the 27 tripartite faculty. In terms of Cabell, seven out of 17 journals were in Cabell's whitelist in the past. Furthermore, seven out of the 17 are not in Cabell's blacklist, and six are under review. ${ }^{29}$

In terms of the business educational journals, Table $4^{30}$ shows that it is highly improbable that these be classified as "predatory". Furthermore, not a single faculty member published more than one article in each of the journals which were found by Crawford to be "weak", "maybe" or "strong" cases.

\subsection{Crawford's Gray OA Journals}

In addition, Crawford produced a report on gray OA journals which was based on Beall's two lists as of 8 July 2016. He defined gray OA journals as "A full survey of journals from open access publishers that aren't in the Directory of Open Access Journals, using Beall's lists as a resource." 31

Crawford recorded and analyzed 18,910 journals. After scanning Crawford's spreadsheet, it was found that only four journals (see Table 5) could be considered as gray OA. All journals were labelled with an A code, ${ }^{32}$ which is a catchall code. All four journals are still operational and they are not in the UA category (i.e., hidden or unknown APCs). One of the journals is not OA. Crawford believed that the UA category (22\% of the still operational gray OA journals) could be considered "predatory" journals as the publisher did not reveal the publication fee to authors. This deceptive act may add an additional layer of concern to the expanding "author-pays-to-publish" OA publishing market [15].

27 Supplementary Table S1 shows the name and URL of these journals/publishers.

28 We remind readers that Crawford's grayOA list was based on evidence from Beall's blacklists that was then used to support their inclusion into his list where Crawford found that over 10,000 journals from a total of about 18,000 were not operational.

29 Cabell indicated to the first author by email on 29 December 2017 that they had added one more journal to their blacklist. From: Kathleen Berryman Subject: RE: Request for an update on journals under review. "There has been only one change: International Academic Research Journal of Business and Management - blacklist." To date (11 April 2019) there are 544 publishers under review by Cabell. Almost all publishers under review can be found in Beall's blacklist of 1163 publishers. Hence, IABE has been under review for almost a year and a half. Furthermore, it would be of interest in the future to assess what classification was done to the 619 publishers that are not under review by Cabell. Were most of the 619 publishers not operational with no content as Crawford found when constructing the GrayOA list from Beall's list?

30 Supplementary Table S1 shows the name and URL of these journals/publishers.

31 See https://figshare.com/articles/Gray_OA_2012-2016_Gold_OA_Beyond_DOAJ/4275860.

32 Most journals were in the A category. B3 was for journals with no articles later than 2013, B4 later than 2014, B5 no 2016 articles, BC merged, BF fewer than three 2016 articles, BR primarily conference proceedings, E empty, UA unknown or hidden $\mathrm{APC}, \mathrm{XH}$ hybrid, $\mathrm{XM}$ malware, $\mathrm{XN}$ not $\mathrm{OA}, \mathrm{Xo}$ opaque and too difficult to count, and $\mathrm{XU}$ for unworkable. 
Table 3. Publications of research faculty members in Beall's 2016 lists and unranked in the 2013 ABDC list.

\begin{tabular}{|c|c|c|c|c|c|c|c|c|c|}
\hline \multirow[b]{2}{*}{ Journal } & \multirow[b]{2}{*}{ Publisher } & \multirow[b]{2}{*}{ \# of Articles } & \multirow[b]{2}{*}{$\begin{array}{l}\text { Crawford } \\
\text { on Beall's }\end{array}$} & \multirow[b]{2}{*}{ Open Access } & \multicolumn{5}{|c|}{ Cabell's Classification } \\
\hline & & & & & $\begin{array}{l}\text { Starting Date of } \\
\text { Inclusion in } \\
\text { Whitelist } \\
\text { (month, year) }\end{array}$ & $\begin{array}{l}\text { Date Removed } \\
\text { from Whitelist } \\
\text { (month, year) }\end{array}$ & $\begin{array}{l}\text { Again Included in } \\
\text { Whitelist } \\
\text { (month, year) }\end{array}$ & $\begin{array}{c}\text { Currently } \\
\text { Whitelisted }\end{array}$ & Blacklisted \\
\hline $\begin{array}{l}\text { Academy of Strategic } \\
\text { Management Journal }\end{array}$ & Allied Academies & 1 & Trust me & $\mathrm{Y}$ & January 1997 & August 2015 & $\begin{array}{c}\text { March } \\
\text { 2016-October } 2016\end{array}$ & No & No \\
\hline $\begin{array}{c}\text { African Journal of } \\
\text { Business Management }\end{array}$ & Academic Journals & 1 & Trust me & $\mathrm{Y}$ & & & & No & Yes \\
\hline Business Studies Journal & Allied Academies & 1 & Trust me & $\mathrm{Y}$ & January 1997 & August 2015 & $\begin{array}{c}\text { March } \\
\text { 2016-October } 2016\end{array}$ & No & No \\
\hline $\begin{array}{l}\text { International Academic Research } \\
\text { Journal of Business and Management }\end{array}$ & $\begin{array}{l}\text { Academic Research } \\
\text { Publishers }\end{array}$ & 1 & Trust me & $\mathrm{Y}$ & April 2012 & July 2015 & & No & Yes \\
\hline $\begin{array}{l}\text { International Business and Economics } \\
\text { Research Journal }\end{array}$ & Clute Institute & 2 & Trust me & $\mathrm{Y}$ & January 2004 & April 2014 & & No & No \\
\hline $\begin{array}{l}\text { International Journal of Applied } \\
\text { Engineering Research }\end{array}$ & $\begin{array}{l}\text { Research India } \\
\text { Publications }\end{array}$ & 1 & Strong & $\mathrm{Y}$ & & & & No & Under review \\
\hline $\begin{array}{l}\text { International Journal of Business } \\
\text { Research and Management }\end{array}$ & CSC Journals & 2 & Trust me & $\mathrm{Y}$ & & & & No & Under review \\
\hline $\begin{array}{c}\text { International Review of Business } \\
\text { Research Papers }\end{array}$ & Zant World Press & 2 & Trust me & $\mathrm{N}$ & & & & & Under review \\
\hline Journal of Business and Economics & $\begin{array}{l}\text { Academic Star } \\
\text { Publishing Co. }\end{array}$ & 1 & Trust me & $\mathrm{Y}$ & & & & No & Yes \\
\hline $\begin{array}{l}\text { Journal of International } \\
\text { Business Research }\end{array}$ & Allied Academies & 1 & Trust me & $\mathrm{Y}$ & January 1997 & August 2015 & $\begin{array}{c}\text { March } \\
\text { 2016-October } 2016\end{array}$ & No & No \\
\hline Journal of Sustainable Development & $\begin{array}{c}\text { Canadian Center of } \\
\text { Science and Education }\end{array}$ & 1 & Weak & $\mathrm{Y}$ & & & & No & Yes \\
\hline $\begin{array}{l}\text { OIDA International Journal on } \\
\text { Sustainable Development }\end{array}$ & Zzind & 1 & Strong & $\mathrm{Y}$ & & & & No & Under review \\
\hline Open Journal of Social Sciences & $\begin{array}{c}\text { SCIRP (Scientific } \\
\text { Research Publishing) }\end{array}$ & 1 & Maybe & $\mathrm{Y}$ & & & & No & Under review \\
\hline The Open Urban Studies Journal & Bentham Open & 1 & Weak & $\mathrm{Y}$ & & & & No & No \\
\hline $\begin{array}{l}\text { The International Journal of Applied } \\
\text { Economics and Finance }\end{array}$ & Science Alert & 1 & Trust me & Y & & & & No & Under Review \\
\hline World Review of Business Research & World Business Institute & 1 & Trust me & $\mathrm{Y}$ & November 2011 & April 2015 & & No & No \\
\hline
\end{tabular}


Table 4. Business educational publications of research faculty members in journals included in Beall's 2016 list of publishers.

\begin{tabular}{|c|c|c|c|c|c|c|c|c|c|}
\hline \multirow[b]{2}{*}{ Educational Journals } & \multirow[b]{2}{*}{ Publisher } & \multirow[b]{2}{*}{ \# of Articles } & \multirow[b]{2}{*}{ Crawford } & \multicolumn{6}{|c|}{ Cabell's Classification } \\
\hline & & & & $\begin{array}{l}\text { Starting Date of } \\
\text { Inclusion in } \\
\text { Whitelist } \\
\text { (month, year) }\end{array}$ & $\begin{array}{l}\text { Date Removed } \\
\text { from Whitelist } \\
\text { (month, year) }\end{array}$ & $\begin{array}{l}\text { Again Included in } \\
\text { Whitelist } \\
\text { (month, year) }\end{array}$ & $\begin{array}{l}\text { Currently } \\
\text { Whitelisted }\end{array}$ & Blacklisted & Open Access \\
\hline $\begin{array}{l}\text { American Journal of } \\
\text { Business Education }\end{array}$ & Clute Institute & 4 & Trust me & January 2010 & April 2014 & & No & No & Y \\
\hline $\begin{array}{c}\text { Journal of } \\
\text { Instructional Pedagogies }\end{array}$ & $\begin{array}{l}\text { Academic and Business } \\
\text { Research institute }\end{array}$ & 1 & Weak & November 2011 & & & Yes & No & Y \\
\hline $\begin{array}{l}\text { Journal of Economics } \\
\text { and Economic } \\
\text { Education Research }\end{array}$ & Allied Academies & 3 & Trust me & January 1997 & August 2015 & $\begin{array}{c}\text { March } \\
\text { 2016-October } 2016\end{array}$ & No & No & Y \\
\hline
\end{tabular}


Table 5. Publications of the 27 research faculty members at a small business school in Canada listed in Crawford's gray open access list.

\begin{tabular}{llll}
\hline Journal & $\#$ & Publisher & Code \\
\hline $\begin{array}{l}\text { International Academic Research Journal of Business and } \\
\text { Management }\end{array}$ & 1 & Academic Research Publishers & XN \\
International Journal of Business and Management & 1 & Canadian Center of Science and & Aducation \\
Journal of International Management Studies & 3 & JIMS & A \\
Theoretical Economics Letters & 1 & Scientific Research Publishing (SCIRP) & A \\
OIDA International Journal on Sustainable Development & 1 & zzind & A \\
\hline
\end{tabular}

\section{Conclusions}

We used Crawford's assessment as well as the 2016 ABDC and Cabell's whitelist and blacklist and found different results than the Study. Of relevance, we found that, once journals and publishers were reclassified using a wider range of more reliable, trustworthy and established whitelists and blacklists, the faculty at the small business school published far less publications in so-called "predatory journals" than the Study claimed. Using Cabell's blacklist, only 10 articles are blacklisted while the Study found 69 publications listed. This constitutes approximately $2.2 \%$ of the total publications of the 27 research faculty. Of these 10 articles, six were published in journals that were ranked in the ABDC list in 2013 while four were from the Beall and unranked category. Using Crawford's gray OA list under "strong predatory", there are only six articles, or eight if we also include the "maybe" category. In addition, five of the eight articles were in Cabell's whitelist in the past and the ABDC 2013 whitelist, and many of these were in the 2016 ABDC whitelist. This huge difference between Beall's blacklisting and that of Cabell or Crawford implies that there is a large type I error (i.e., false positives) in the Study's assessment using Beall's blacklists. It is possible that academics may have been "victims", but that would also imply that Cabell International and ABDC were also victims. We believe that faculty members published in these journals because they preferred an OA choice, even though we detected that some publishers were not OA (e.g., IABE).

Supplementary Materials: The following are available online at http://www.mdpi.com/2304-6775/7/2/35/s1, Table S1: URLS of journals and publishers listed in Tables 2-4 of the main text.

Author Contributions: Conceptualization, P.T. and J.A.T.d.S.; methodology, P.T. and J.A.T.d.S.; validation, P.T. and J.A.T.d.S.; formal analysis, P.T.; investigation, P.T. and J.A.T.d.S.; data curation, P.T.; writing-original draft preparation, P.T. and J.A.T.d.S.; writing—review and editing, P.T. and J.A.T.d.S.; visualization, P.T. and J.A.T.d.S.; supervision, P.T. and J.A.T.d.S.; project administration, P.T. and J.A.T.d.S.

Funding: This research received no external funding.

Acknowledgments: The authors thank the assistance of Ms. Kathleen Berryman (Project Manager, Cabell Scholarly Analytics, Cabell's International, Beaumont, TX, USA; https://www2.cabells.com/).

Conflicts of Interest: The authors declare no conflict of interest. However, the first author of this paper (Panagiotis Tsigaris), who works at the same institute as Derek Pyne, could be perceived as biased, in that he has been affected by Pyne's work, and may have an interest in rebutting his conclusions.

\section{References}

1. Beall, J. What I learned from predatory publishers. Biochem. Med. 2017, 27, 273-278. [CrossRef] [PubMed]

2. Beall, J. Predatory journals: Ban predators from the scientific record. Nature 2016, 534, 326. [CrossRef] [PubMed]

3. Teixeira da Silva, J.A.; Tsigaris, P. What value do whitelists and blacklists have in academia? J. Acad. Librariansh. 2018. [CrossRef]

4. Altman, D.G.; Bland, J.M. Diagnostic tests. 1: Sensitivity and specificity. BMJ Br. Med J. 1994, $308,1552$. [CrossRef] [PubMed] 
5. Olivarez, J.D.; Bales, S.; Sare, L.; Van Duinkerken, W. Format aside: Applying Beall's criteria to assess the predatory nature of both OA and non-OA library and information science journals. Coll. Res. Libr. 2018, 79, 52-67. [CrossRef]

6. Teixeira da Silva, J.A. Caution with the continued use of Jeffrey Beall's "predatory" open access publishing lists. AME Med. J. 2017, 2, 97. [CrossRef]

7. Teixeira da Silva, J.A. Jeffrey Beall's "predatory" lists must not be used: They are biased, flawed, opaque and inaccurate. Bibliothecae.it 2017, 6, 425-436. [CrossRef]

8. Teixeira da Silva, J.A. The illicit and illegitimate continued use of Jeffrey Beall's "predatory" open access black lists. J. Radic. Librariansh. 2018, 4, 1-5.

9. Cobey, K.D.; Grudniewicz, A.; Lalu, M.M.; Rice, D.B.; Raffoul, H.; Moher, D. Knowledge and motivations of researchers publishing in presumed predatory journals: A survey. BMJ Open 2019, 9, e026516. [CrossRef] [PubMed]

10. Crawford, W. 'Trust Me': The Other Problem with $87 \%$ of Beall's Lists. January 2016. Available online: http://walt.lishost.org/2016/01/trust-me-the-other-problem-with-87-of-bealls-lists/ (accessed on 11 April 2019).

11. Pyne, D. The rewards of predatory publishing at a small business school. J. Sch. Publ. 2017, 48, 137-160. [CrossRef]

12. Teixeira da Silva, J.A. The ethical and academic implications of the Jeffrey Beall (www.scholarlyoa.com) blog shutdown. Sci. Eng. Ethics 2019. [CrossRef] [PubMed]

13. Tsigaris, P. Letter to the editors. J. Sch. Publ. 2019, 50, 139-142. [CrossRef]

14. Fazio, L.K.; Brashier, N.M.; Payne, B.K.; Marsh, E.J. Knowledge does not protect against illusory truth. J. Exp. Psychol. 2015, 144, 993-1002. [CrossRef] [PubMed]

15. Al-Khatib, A.; Teixeira da Silva, J.A. Threats to the survival of the author-pays-journal to publish model. Publ. Res. Q. 2017, 33, 64-70. [CrossRef]

(C) 2019 by the authors. Licensee MDPI, Basel, Switzerland. This article is an open access article distributed under the terms and conditions of the Creative Commons Attribution (CC BY) license (http://creativecommons.org/licenses/by/4.0/). 